\title{
An Interesting Condition: The Abortion Pastels of Paula Rego
}

\author{
Maria Manuel Lisboa
}

\begin{abstract}
No texto que se segue serão debatidos alguns dos quadros a pastel de Paula Rego, de 1999, sobre o tema do aborto. A proposta de interpretação aqui apresentada procura situar os quadros em questão em dois contextos, nomeadamente teórico e político-social. No plano teórico situa-se a apresentação do corpo feminino que em Paula Rego, e em eco deliberado ou inconsciente de todo um panorama de considerações teóricas feministas no campo das artes plásticas, têm debatido a representação daquele, nos cânones das artes. E no pelouro politico, deparamos com a reaç̧ão que primariamente motivou esta série de quadros, nomeadamente $o$ debate legislativo, social e religioso em tomo da questão da legalização do aborto em Portugal em 1998.
\end{abstract}

In what follows I shall be considering a series of ten pastels by Paula Rego produced from fourteen sketches over a period of approximately six months, between July 1998 and February 1999. The motivation behind these works was a political event in Portugal, namely the referendum on abortion on 28 June 1998, in the aftermath of legislation that liberalized the existing abortion laws. The effect of the referendum, details surrounding which will be outlined presently, was to bring about the suspension of the law, for the purpose of its subsequent reconsideration by Parliament.

This essay will seek to place the abortion pastels, which unprecedentedly for this artist remain untitled, within the context of the political upheaval created in Portugal by the referendum, as well as within the wider scenario of abortion debates worldwide. As has so often been the case in Paula Rego's work, yet more directly so here, her images are rooted in a pre-existing context whose nuances inform the resulting pictures and are central to their meaning.

The above statement gestures towards areas of theoretical debate which the reading that follows should wish if only briefly to acknowledge, namely the long-standing polemic between New Historicists or Cultural Materialists on the one hand and Postmodern and Poststructuralist methodologists on the other. ${ }^{1}$ The interpretative strategy employed in what follows situates itself within a New Historicist practice summed up by Jeremy Hawthorn as follows:

The particular reading strategies with which I am concerned are those which can be loosely termed 'historicist', those that are committed to the belief that literary works are most fruitfully read in the illuminating contexts of the historical forces which contributed to their birth and the historically conditioned, and changing circumstances of their subsequent life. Such a project requires that one have some conception of the ways in which human beings relate to the past, the ways in which they trace the cunning passages of history and depict them in cunning passages of their own. ${ }^{2}$ 
If, contrary to Derrida's notorious statement that "il n'y a pas de hors-texte,"3 a New Historicist method concerns itself with a context beyond the text, the further implications of this latter theoretical commitment will also need to counter the rejection, which Poststructuralism and Postmodernism share, that in historical as in critical reading, it is impossible to privilege one interpretation over another as being the truth of the event in question. ${ }^{4}$ For Lyotard, in his by-now enshrined formulation,

it is therefore impossible to judge the existence or validity of narrative knowledge on the basis of scientific knowledge and vice-versa: the relevant criteria are different. All we can do is gaze in wonder at the diversity of discursive species, just as we do at the diversity of plant or animal species. ${ }^{5}$

Norman Bryson sums up the post-structuralist rejection of context in favour of intertextuality as follows:

I would say that Barthes established the intertextual text in two moves. The first involves the severance of the text from reference to a real world beyond itself. [...] This first move, the separation of text from reference to a real world, is completed in the second move, which disconnects the text from authorial intention. In "The Death of the Author," Barthes wrote that a text is "not a line of words releasing a single 'theological' meaning (the message of the Author-God) but a multidimensional space in which a variety of texts, none of them original, blend and clash." Barthes's idea of the text is such that, disconnected from authorial intention on the one hand and from reference to a world beyond the text on the other, it becomes an intertextual field where no discursive fragment is bound to any origin whatever. In the field of the text, fragments of other texts blend, clash, collide; each text is the reflection of other texts in a swirl of mobile intertextualities. $^{6}$

The theoretical material outlined refers on the whole to literary texts. For the purpose of the ensuing analysis the term "text" is taken here to apply also to visual images. The textualism/contextualism debate gives rise to two categories of problem that confront critics and theorists involved in a return to history in their practice. On the one hand they must engage with the textualist claim that denies the possibility of a valid reinscription of a text in history by virtue of the inaccessibility of historical truth itself. History is text, and any of a multitude of interpretations of any given event is as valid as any other. On the other hand they are obliged to counter a traditionalism that has faith in the possibility of linking historical accounts (history discouse) to an objective reality, but excludes the possibility of a literary text (seen as a purely aesthetic phenomenon) appealling effectively to historical truth. For Hawthorn, "the first of these solutions trivializes literary texts along with all other texts; the second restores the importance of historical texts at the cost of again trivializing literary ones":

The existing answers of new textualists and of old historians (and old aesthetes) are found to be equally unacceptable. What is required of such answers is that they provide some means to justify the importance of literary texts which goes beyond that of providing documentary historical evidence. [...] This has involved attempts to analyse and display the various and complex ways in which literature interlocks with social and historical realities. In particular, it has involved attempts to grapple with the complex ways in which literary works arise out of and engage with a reality that may be mediated through texts or discourses, but which also exists independently of them. ${ }^{7}$ 
Linda Hutcheon's take on Postmodernism partly sidesteps or contests the intellectual and political difficulties that accrue to the affirmation of absolute interpretative arbitrarism (so that any interpretation of an event, such as, for the sake of polemical edge, "the Holocaust never happened," is as valid as another, such as "the Holocaust did happen"). For her, Postmodern art is "fundamentally paradoxical in its relation to history: it is both critical of and complicitous with that which precedes it." It follows, however, that even the postmodern condition Lyotard has written about tacitly acknowledges the palpability and existence of that reality or history it critiques, at least in as much as it exists textually (the grands récits or master narratives), but has an impact extratextually:

The postmodern does not deny its inevitable implication in them, but it also wants to use that "insider" position to problematize the "givens" that "go without saying" in those grand systems. Thus, it is neither neoconservatively nostalgic nor radically revolutionary; it is unavoidably compromised and it knows it. [...] It clearly intends to problematize, for instance, the entire notion of representation in high art as well as mass media, and it succeeds in so doing. But it has consistently done so from within the conventions it seeks to dismantle and destabilize. ${ }^{9}$

Whether present in a formative or merely in an informative manner, to a greater or lesser degree, history (for which read broadly society, politics and ideology) - that "uncircumventable phantom of history" which Deborah Lipstadt calls "irrefutable" ("Slavery happened; so did the Black Plague and the Holocaust" ${ }^{\circ}$ ) and which Saul Friedlander defined as "something irreducible which, for better or worse, I would still call reality" - lies at the root of the approach to be taken here, with regard to these most historical of all of Paula Rego's admirably pamphleteering art.

Jürgen Habermas, Frederic Jameson, Elizabeth Bronfen and more specifically with reference to painting Mieke $\mathrm{Bal}$ have written of the masterplots that have habitually colonized or erased the marginal. ${ }^{12}$ Bal focuses on the "incoherent" detail that challenges the convention of unity in painting as a powerful ideological weapon. And Naomi Schor, ${ }^{13}$ to give but one example, has discussed at length the aesthetics of detail as being possessed of a gender charge that, for Bal, demarcates the arena in which "a battle over the marginality of women is fought." ${ }^{14}$ Elsewhere I have discussed the impact of such details in some of Paula Rego's implicitly historical paintings. In what follows below, I shall attempt the historical inscription of some of this artist's abortion pastels within a national context whose chronology is clearly delimited by the events outlined in the opening paragraphs of this text, namely the abortion referendum in Portugal in 1998.

In so doing, however, I shall also attempt to identify the sleight of hand whereby this artist, in a manoeuvre by now familiar to followers of her work throughout the last four decades, conflates two seemingly mutually exclusive events, positions or historical moments (in this case pre- and post-democracy Portugal), and instead renders explicit their uncomfortable shared territory. In Paula Rego's 1998 abortion pastels, I should wish to argue, what is in play is the master narrative of a contemporary Portugal complacent about its nouveau-democratic status but confronted with its uneasy proximity to and affinities with the recent dictatorial past. The cornerstone for this Regoesque polemic conducted on two fronts, against the grands récits of Portuguese fascism and present-day democracy, is the connecting thread of abortion. Abortion, or the debate surrounding it becomes the inconvenient shared territory that turns political opposites (fascism and democracy) into tacit fellow travellers. One aspect of the abortion polemic that is of direct import to these pictures is the enduring fact of Catholic influence, arguably unchanged both in pre- and postdemocracy Portugal. I should wish to begin, therefore, by introducing some points regarding 
the Catholic Church's longstanding intervention in public affairs (specifically sexual politics) in general and in Portugal in particular.

\section{The Catholic Church and the Abortion Debate}

Referring to Machiavelli's principle of a form of morals without scruples, such that the basis for success was that might is right, Lloyd Cole contends that this concept accurately describes the impact of the Roman Catholic church in countries where it exercises significant control over the population, and over its reproductive, including contraceptive, practices. ${ }^{15}$

Janet Hadley gives a lucid account of how the abortion controversy has set the agenda of wider national politics at various points, or in some cases more or less perennially, in countries such as Ireland, Poland, Germany and the United States. In March 1993 a gynaecologist, David Gunn, was killed by anti-abortion activists ${ }^{16}$ outside his Florida abortion clinic and since then the violence has escalated with further killings. In spite of this, and in spite of some sectors of the Catholic faithful having distanced themselves from the "vengeful Old Testament mentality" of "extremists who have hijacked the American pro-life movement," 17 in March 1995, two years after that first killing in the United States, the pope issued his eleventh encyclical, Evangelium vitae ("Gospel of life"), urging all Catholics to consider themselves under a "grave and clear obligation" to join non-violent anti-abortion protests. According to Hadley, "The pope's message came within inches of endorsing antiabortion militancy as a religious duty and the mainstream lobbyists fretted that it would whip up the fanatics to further image-damaging antics." 18

Not surprisingly, then, both before and after the pope's encyclical, anti-abortion Catholic thought as well as the extremist factions of the anti-abortion lobby have continued to equate abortion with genocide and with the euthanasia practices of the Nazis against the physically and mentally handicapped. Some writers further view the opposition to abortion as operating in tandem with an implicit declaration of wider sexual-political import (control over the bodies and roles of women), and one which furthermore entails a theological/doctrinal dimension. This refers primarily to the Christian/Catholic view that the reproductive function is the paramount role of women, ordained as either a punishment (for example childbirth in pain as attonement for the original sin of Eve, Humanity's first Mother), or as a privilege (the emulation of the cultural and religious icon of the Virgin Mary as Holy Mother). Motherhood, according to this precept, becomes neither a choice nor an option, but instead a divinely ordained and inescapable imposition.

In Genesis God admonishes Eve that in retaliation for her disobedience "I will greatly multiply thy sorrow and thy conception; in sorrow thou shalt bring forth children; and thy desire shall be to thy husband, and he shall rule over thee." ${ }^{19}$ In this passage woman's criminality, her maternity, and her subjection to the male are neatly linked together and transmitted in perpetuity to all womankind. To all womankind, that is, until the advent of Mary, whose redemptory coming into being had the power if not fully to cleanse, at least to set a good example to all her female descendants. Her all-embracing purity beautifies even Eve's sin, which it transforms into a Felix Culpa, a Fall now blessed for having made Mary's own idolized existence necessary. ${ }^{20}$ Childbirth, and more specifically the pain it entails, was the punishment for the woman's greater share in Original Sin. Both the womb and the child in it were stained by that sin: "Woman was womb and womb was evil," 21 therefore woman was evil, and that syllogism endured until the advent of Mary, whose essence too was maternity, but now a hallowed, purifying and redemptory maternity to which other women could aspire, while however, and paradoxically, knowing that they could never emulate it.

Mary stands as the exception to the human and female plight in two respects: she is exempt from original sin and she achieved motherhood while simultaneously retaining her 
virginity. At an abstract level, therefore, she represents a philosophically and emotionally insurmountable problem for women: she is held up as that which they ought to strive to be while being admonished that, being different from her in those two respects, they can never approximate her privileged status. ${ }^{22}$ At a more pragmatic level, Mary has been the vehicle for the promotion of a series of political and ideological interests that depended or at least relied upon the reproductive subjection of women as one of its central tennets:

[...] In Catholic countries above all, from Italy to Latin America [...] women are subjugated to the ideal of maternity. [...]

The natural order for the female sex is ordained as motherhood and, through motherhood, domestic dominion. The idea that a woman might direct matter in her own right as an independent individual is not even entertained. In Catholic societies, such a state of affairs is general, and finds approval in the religion's chief female figure. ${ }^{23}$

The writer of the above lines goes on to expand how propaganda of this sort, and the conflicts it throws up, extend well outside the sphere of theological debate, and into real politik:

In 1974 Pope Paul VI, sensitive to a new mood among Catholic women, attempted to represent [Mary] as the steely champion of the oppressed and a woman of action and resolve. She should not be thought of, he wrote, "as a mother exclusively concerned with her own divine Son, but rather as a woman whose action helped to strengthen the apostolic community's faith in Christ."24

When Pope Paul VI help up Mary as the New Woman, the model for all Christians, he expressed this impossibly divided aim without irony, in the immemorial manner of his predecessors. The Virgin is to be emulated as "the disciple who builds up the earthly and temporal city while a diligent pilgrim towards the heavenly and eternal city." 25

Earlier dictates of this sort were directly put to use in Portugal by the propaganda machinery of Salazar's right-wing dictatorship, Estado Novo, between 1933 and 1974. Their effect, however, outlasted the fall of the regime, as demonstrated by the nature of the polemic thrown up in the context of the abortion referendum fifteen years later.

The relationship between Church and State in Portugal has always been and remains complex. Never more so, however, than under the Estado Novo. Salazar's regime had promoted a package-deal approach to national life, which envisaged the traditional family set-up of an authoritative working husband, a domestically confined wife and their numerous (because unplanned) children, as shoring up the political fabric of a nation whose ruler sought to present himself as the Pater Familias of the nation.

A fair amount has been written about the conditions of suffocation and oppression accruing in general but to women in particular in Portugal under Salazar, conditions which for example saw women unable to work, hold a passport or have a bank account, without their husbands' formal written consent. In 1940 the interests of the Church and State were officially intertwined through the signing of a Concordat with the Vatican that officialized, among other things, the state's desire to enforce upon women the imperative of emulating the cultural maternal icon of the Virgin Mary as the only acceptable role model of femininity. Domesticity, chastity, obedience and submission to the husband as official head of the family ("chefe de familia") and through him to Salazar as Head of State and to God as Universal Father were all officially preached by Salazar's ministerial dictates: 
Women's work outside the family sphere disintegrates home life, separates its different members, and makes them strangers to each other... Life in common disappears; the work of educating the children suffers and families become smaller. [...] We consider that it is the man who should labor and maintain the family and we say that the work of the married woman outside her home, and, similarly that of the spinster who is a member of the family, should not be encouraged. ${ }^{26}$

The great nations should set an example by confining women to their homes. But these great nations seem oblivious to the fact that the solid family structure cannot exist where the wife's activity is outside the home. And so the evil spreads and each day becomes more dangerous. What can I do, I myself, in Portugal? I know only too well, alas, that all my efforts to bring women back to older ways of living have remained practically useless! $!^{27}$

Salazar was too modest about his own achievements. These statements, made in the context of a Catholicism that Paula Rego has described as "scary" and "ridden with guilt,"28 were prefigured by the shadowy spectre of a Marian worship that directly served the patriarchal interests of the State and the theological necessities of the Church. Of particular interest among the many legislative measures passed under Salazar and aimed at regulating the position of women under the law, was the 1967 new Civil Code, which severely attacked the area of married women's rights. It stated that "the husband is the head of the family, and as such he is to decide and direct on all matters concerning marital life. [...] It is the father, as the head of the household, who directs the children's education, and governs them, according to their sex, defends and represents them even before they are born." 29 The reach of this legislative measure obviously extended to the matter of abortion.

Many of Paula Rego's paintings of the last twenty years, and most specifically her recent exhibitions in London, Lisbon and Madrid in 1998 and $1999^{30}$ have addressed themselves to the Church-State conglomerate, and to the undemocratic consequences of their collusion, both under monarchy in the nineteenth century and under Salazar's regime in the twentieth. Furthermore, in the recent series of pastels on the subject of abortion, she addressses herself to what some would see as the unexpected and enduring power of Catholicism over the lives, minds, and, more to the point, politics of the nation in current post-Salazar Portugal, under a democratic Socialist government.

Under Salazar Portugal enforced one of the strictest abortion laws in the Western world. Abortion was illegal and punishable with a term of prison, decriminalization applying only in the case of proven danger to the life of the mother or severe malformation of the foetus, in which case a conference of medical practitioners might decide upon a technically illegal but non-prosecuted abortion.

In 1984 , ten years after the revolution that ushered in democracy, the law was changed to legalize abortion in three specific circumstances: up to 12 weeks (and in some cases with no established upper limit) in the case of danger to the life or irreversible damage to the health of the mother; up to 16 weeks in the case of incurable illness or malformation of the foetus; and up to 12 weeks if the pregnancy was the result of rape. In every case the abortion was to be carried out by a doctor in a recognized medical establishment. The new law, like the old one, recognized a doctor's right to conscienscious objection, and punished abortion in all other circumstances by 2 to 8 years' imprisonment. ${ }^{31}$

An attempt at further liberalizing the law by introducing abortion on demand up to 10 weeks was rejected by Parliament at the beginning of 1997, but it was included in the agenda of the following year's Parliamentary debate, under a motion by JS (Socialist Youth) and PCP (Portuguese Communist Party). The proposed law was interpreted by many as being of 
an anti-punitive, rather than liberalizing tendency ${ }^{32}$ and it was approved in 1998, but a referendum on it was immediately requested by a coalition of centre-right factions. Under Portuguese law it is unconstitutional to hold a referendum on a law already approved by Parliament but the government agreed to it nonetheless. The Catholic Church, although clearly opposed to the law, was divided on the issue of whether it was feasible to hold a referendum on the right to be born, as well as on the advice to be given to the faithful on the matter of voting.

The referendum was set to take place on 28 June 1998, and debate on the matter hijacked press time and newspaper column inches in the months that followed. Public, political and religious opinion was divided, and the result of the referendum was a deadlock. Only a disappointing $31.94 \%$ of the electorate voted $(2,711,712$ voters). Of these, $49.08 \%$ or $1,308,631$ people voted in favour of liberalization. By the tiniest margin, of just over one percent, the no vote won: $50 \% 92(1,357,914)$ voted against the liberalizing option. In view of the inconclusiveness of the result, it was decided that the law would have to be resubmitted to Parliament for further consideration at a later date. The matter remains unresolved at the time of going to press.

One final fact may offer food for thought. In the debate leading up to the referendum, a survey of medical opinion found that a significant number of the doctors questioned indicated that even were the law to be supported by the referendum or otherwise upheld, they themselves would neither offer abortions in their hospitals or practices, nor commit fundings to its implementation on demand, suggesting that considerable problems remain as regards making the law a practical reality for many Portuguese women. ${ }^{33}$

The issue of problematic motherhood, which continues to divide the nation at present, becomes particularly poignant in the context of the background of the artist in question here. Paula Rego is a Portuguese painter who has lived in London all of her working life, but who acknowledges in her work enduring atavistic bonds to the national reality she hails from. In one way or another much of her work from the early 1960s onwards has engaged in open confrontation with the religious and undemocratic imperatives that defined political life in Portugal for much of this century. ${ }^{34}$ She has also concerned herself more particularly with the problems of women under dictatorship and beyond.

The Carnation Revolution of 1974 reestablished democracy in Portugal, and opened the way for massive and rapid changes in women's living and working conditions. As observed above, however, the events surrounding the referendum on abortion made clear to what an extent religious influence and traditional attitudes about women and motherhood still endure in the Portuguese psyche. Politically and clerically enforced unwanted maternity is still a reality in Portugal today, and Paula Rego's Untitled (silenced) works speak loudly about the problems that continue to prevail under the current status quo.

\section{SOMe TheOretical PoINTS}

In the course of the following analysis of Paula Rego's abortion pastels it may be worth bearing in mind the way in which the choice of theme itself contravenes habitual preferences in the tradition of the visual arts in the West. "Birth has almost everywhere been celebrated in painting. The Nativity has been a symbol of gladness, not only because of its sacral significance, but because of its human meaning - 'joy that a man is born into the world.' Abortion, in contrast, has rarely been the subject of art. Unlike other forms of death, abortion has not been seen by painters as a release, a sacrifice, or a victory. Characteristically it has stood for sterility, futility, and absurdity." 35

Abortion clearly stands as the exact antithesis of the initiatory (and iconographic) moment of Annunciation. ${ }^{36}$ And whereas the much depicted Annunciation gestures towards a 
new beginning, a world without end, abortion declares untimely closure for the child (if not for the mother for whom it might after all signal the possibility of a fresh start). Be that as it may, abortion, while being the act that contravenes the "joy that a man is born into the world," carries significances that extend well beyond the threat of sterility, futility and absurdity. At the secular level, the nipping in the bud of that specifically male birth ("a man born into the world"), interrupts the continuity of both divine and human male lineages of blood, name, property and power. And at the sacral level, it gestures towards the heresy of a contingency such that the culmination of a theological trajectory leading from God-theFather to his divine and human progeny is not a Sacred Son alive and immortal, but a dead foetus inside a bucketful of blood. Abortion in the context of a biblical referent must be seen to be the referent also of the Rego pictures (gesturing as they do to Catholic intervention in a secular legislative debate). As such both it and the pictures in question evoke three concepts excised from any biblical wish-list of desirability. First, the reinstated emphasis on the postlapsarian labour(ious) childbirth of Eve in place of the blessed one of Mary that supposedly overrode it. Second, fruitless travail with no child at the end of it, rather than redemptory birth. Third, and associated to the latter, the issue (outcome) of the abortion crime (blood and gore), rather than a sacred Issue (the pure fruit of divinely annointed loins, namely a Holy Child).

The topic of abortion, therefore, sets off resonances so disturbing that they may explain the rarefaction of its translation into canonical visual images. When, as in the Paula Rego images in question here, the subject is taken up and developed, its wider implications may open other disruptive avenues of thought.

In Ways of Seeing, John Berger writes that "men look at women. Women watch themselves being looked at. The surveyor of the woman in herself is male; the surveyed female. Thus, she turns herself into an object." ${ }^{, 37}$ Similar points have been made in film theory, notably by Laura Mulvey with reference to the arousal of pleasure in cinematic viewing, in what are by now canonical essays. ${ }^{38}$ Both these writers raise a series of questions that may be pertinent in relation to Paula Rego's abortion pastels. First, in many of these images, as is so often the case with this artist, the import of the gaze projected out of the picture plane by its subject who in turn is gazed at by the spectactor, is equivocal. In two of the abortion pastels, the female subject, untraditionally in terms of canonical composition, looks straight back at the viewer, thus establishing a mood of participation rather than passive self-exposure to external contemplation (for example n. 1). This declaration on the part of the solo female subject of what must be seen at the very least as awareness of a voyeuristic eye focused on her, can extend to defiance. This is all the more startling in view of the theme of the pictures, each of which depicts a woman either being aborted/aborting herself, or immediately pre- or post-abortion, but in any case involved in an act that presupposes clandestinity and shame, rather than brazenness. Compositional decisions such as the posture or direction of gaze of the pictorial subject come in this way to feed directly into a sexual-political dimension, in two ways. First they do so through the overturning of aesthetic conventions regarding the depiction of gazed-upon but ungazing female subjects, nude or not. No longer, it would appear, are women to be seen but not seers. And second, as we shall see, they do it through the polemical dialogue set up with socio-moral and legal (specifically Portuguese) attitudes concerning the onus of guilt and sinfulness or criminality habitually expected to accrue to a woman/girl engaged in the act of abortion.

Berger's and Mulvey's essays open up a wealth of questions concerning the matter of pleasure in viewing. Is there a difference between the assumed male spectator of a Playboy magazine nude and the admirer of a Botticelli Venus, an Ingres Odalysque or a Renoir bather? Or, more to the point, is there a difference between a Renoir little demoiselle playing with her hoop and a Paula Rego uniformed school girl, who happens to be in the throes of 
abortion pain (n. 4)? Clearly there is a difference. But there may also be a more worrying similarity, which refers to areas of cryptic and shameful gratification.

Feminist art theory has drawn upon concepts developed also in other branches of cultural theory to explore the ramifications of erotic interaction between the sexes in the visual arts. Lise Vogel, for example, uses as her departure point the well-established debate on images of duality in the portrayal of women (virgin versus whore, queen versus slave, Madonna versus Fury), which she takes to be "simple projections of 'human' (ie. male) fears and fantasies." ${ }^{39}$ Carol Duncan argues along similar lines that "the modern art that we have learned to recognize and respond to as erotic is frequently about the power and supremacy of men over women:" 40

The erotic imaginations of modern male artists - the famous and the forgotten, the formal innovators and the followers - reenact in hundreds of particular variations a remarkably limited set of fantasies. Time and again, the male confronts the female nude as an adversary whose independent existence as a physical or spiritual being must be assimilated to male needs, converted to abstractions, enfeebled, or destroyed. So often do such works invite fantasies of male conquest (or fantasies that justify male domination) that the subjugation of the female will appear to be one of the primary motives of modern erotic art.

[...] The equation of female sexual experience with surrender and victimization is so familiar in what our culture designates as erotic art and so sanctioned by both popular and high cultural traditions, that one hardly stops to think it odd. ${ }^{41}$

Duncan goes on to argue that implicit in this project of domination is the requirement of female pain, a factor which rather than contradicting underwrites the promise of male gratification. With reference to Michelangelo, Ingres, Courbet, Renoir, Matisse, Delacroix, Munch, Klimt, Moreau and many other old and new masters, she discusses the wealth in the visual arts of images of monstrous women, the dread of whom reflects projected male feelings of inferiority. And Griselda Pollock contends that " $[a]$ rt is where the meeting of the social and the subjective is rhetorically represented to us. [...] What we are doing as feminists is naming those implicit connections between the most intimate and the most social, between power and the body, between sexuality and violence. Images of sexual intimidation are central to this problem and thus to a critique of canonical representation. ${ }^{, 42}$ More numerous even than this kind of image, I would now suggest, are the antidotes to these nightmarish females, the multitudes of blessed madonnas, mater dolorosas or, according to Duncan and more to the point, suffering heroines: "slaves, murder victims, women in terror, under attack, betrayed, in chains, abandoned or abducted."43 Their pain becomes the warranty of their controllability by the opposite sex. I should wish to argue that the idealization of variously suffering, helpless, passive women who are the victims, handmaidens or more crucially mothers of a series of lordly males, is not devoid of complexity, since for a woman to be a mother she must either be the Virgin Mary, or she must have had sex like Eve, and suffer for it. In other words she must be either not in fact a woman but rather "young, her body hairless, her flesh buoyant, [devoid of] a sexual organ"44 — in short, both virginal and infantilized - or alternatively she must be a whore, and both visible and punishable as such. And since, as we know, with one single exception women cannot be both virgins and mothers, a mother (Eve) must also by definition be always partwhore. 


\section{The IMAge as Problem Child}

Other instances of the adumbration of what technically are mutually exclusive categories of representation offer viewers-against-the-grain a welcoming foothold. Feminist art criticism has debated with considerable inspiration the conflation of, for example, the two separate genres of pregnancy and nudity in the maternal nude of artists such as Paula Modersohn-Becker and Käthe Kollwitz. ${ }^{45}$ If, as Rosemary Betterton would have it, "[f]or both artists, the "maternal nude" was one means by which they could address issues of their own sexual and creative identity at a time when the roles of artist and mother were viewed as irreconcilable, ${ }^{, 46}$ an analogous process of deployment of counter-intuitive category-pairings might be said to be afoot in Paula Rego's gallery of fully-clothed, mock-erotic aborting women. Trouble begins to arise in this particular, neatly dichotomous, painterly paradise of virgins and whores, when, as is the case with the Rego abortion pictures, the woman who clearly lapsed and sinned, and who moreover is about to compound that sin of fornication with the crime of abortion, carries not the accoutrements of the whore, but rather all the hallmarks of the coltish or half-grown, newly-fledged, hairless and untouched girl-child ( $\mathrm{n}$. 4). If art production has traditionally presupposed the presence of a male viewer and the requirement of male gratification, Paula Rego here, rather than turning the tables on that tradition in a variety of possible, would-be feminist ways (for example, by addressing herself to an implied female audience, as much of her work has been held out to do) may be playing precisely on those two time-honoured assumptions: first, an assumed male gaze, and second, one which, following Duncan, is gratified by these scenes of female pain. The atttempted resolution of these two matters gains complexity, furthermore, as one considers the posture and identity of the female subject. As regards posture, a cursory glance suggest that pictures such as nos. 4, 6 and 7 reproduce the standard reclining posture of any number of eroticized painters' models (adult women models) throughout numerous countries and centuries of visual art production. In fact, however, a closer look problematizes this initial impression and the reflex of erotic response: the models are not women but girls, and their posture is not one of sensual invitation but wracking pain.

Pleasure (the male viewer's) and pain (the girl models'), therefore, become immediately and dangerously indistinct, potentially suggesting two things: first, the foregrounding of a fact that has also habitually been a moral imperative, and that canonical art, while traditionally presupposing, euphemistically sweeps under the carpet: namely that for women, sexual delight inevitably carries a sting in the tail, and may have to be purchased at a high price; and second, that for the male viewer, that pain is the point underpinning the pleasure. The blurring of categories of enjoyment and suffering, furthermore, in the context of these pictures, draws attention to other potential ambivalences, for example between childbirth (consecrated) and abortion (condemned), or between perpetuity (life) and closure (termination of life), or between fruitful and fruitless labour. I would argue that in Rego these points are kept deliberately ambivalent and therefore enduringly preoccupying. In these pictures, cryptically, were it not for the conspicuous absence of any babies, some of the images in question could equally refer to straightforward birthing or Nativity scenes (triptych b). Alternatively, they might also be mistaken for representations of invitation to male penetration (triptych b). However, they refer instead to female anguish without fruit and to possible sexual coercion of various kinds (rape, abuse, incest, power-imbalanced sex between grown men and young girls). And furthermore, they potentially signal male pleasure derived at the price of this anguish (the sexual act that led to the pregnancy) as well as from the contemplation of the anguish itself (as depicted in its visual representation). Angela Carter coined the term "moral pornography" for material that albeit conventionally 
pornographic might, by its very nature, render explicit certain aspects of pleasure exacted at the price of pain within the parametres of gender conflict:

The sexual act in pornography exists as a metaphor for what people do to one another, often in the cruellest sense [...].

And all such literature has the potential to force the reader to assess his relation to his own sexuality, which is to say to his own primary being, through the mediation of the image or the text. This is true for women also, perhaps especially so, as soon as we realize the way pornography reinforces the archetypes of her negativity and that it does so simply because most pornography remains in the service of the status quo. [...]

It is fair to say that, when pornography serves [...] to reinforce the prevailing system of values and ideas in a given society, it is tolerated; and when it does not, it is banned. [...]

When pornography abandons its quality of existential solitude and moves out of the kitsch area of timeless, placeless fantasy and into the real world, then it loses its function of safety valve. It begins to comment on real relations in the real world. Therefore, the more pornographic writing acquires the techniques of real literature, of real art, the more deeply subversive it is likely to be in that the more likely it is to affect the reader's perceptions of the world. [...]

A moral pornographer might use pornography as a critique of the current relations between the sexes. [...] Such a pornographer would not be the enemy of women, perhaps because he might begin to penetrate to the heart of the contempt for women that distorts our culture [...].

And that is because sexual relations between men and women always render explicit the nature of social relations in the society in which they take place and, if described explicitly, will form a critique of those relations. ${ }^{47}$

Paula Rego's pictures draw upon but also reverse some of the concepts outlined by Carter above, by foregrounding the insidious aspect of pain at the heart of the pleasure principle at stake in canonical art. Her abortion images are travesties of a variety of standard iconographic compositions (annunciations, nativities, reclining nudes, sexual frolics), and as such achieve a tripartite chain reaction. First, they lure the gaze into a mood of expectant gratification (as encouraged by the superficial similarity between these images and the standard reclining lovelies of Titian, Ingres, Rubens, Renoir and almost any renowned painter of the female figure down the centuries. The appeal, however, becomes quickly mingled with the shock of realization, as awareness of the actual subject matter dawns. Perversely, however, it is possible that that afterthought of quasi-Aristotelian fear and pity (which technically ought to lead to the purification of catharsis), ${ }^{48}$ in its turn may give way to the titillation and frisson of perverse (and perverted) pleasure, originating in someone else's pain. A pleasure which in any case, as discussed above, arguably constitutes an important component of the master-slave relationship between male viewer-victimized female object in much canonical art.

Mieke Bal has discussed the agency of certain features of protagonist gaze in painting as "a counter to the voyeuristic effect in that the woman's unwillingness to communicate with the viewer problematizes the latter's position." ${ }^{, 49}$ In Paula Rego's abortion pastels, the anti-viewer sleight of hand is of a somewhat different nature, since what is largely at stake appears to be an unsettling awareness of indifference to the viewer. It is a cliché of human 
relations that indifference may be more disturbing than enmity. Some of Paula Rego's protagonists, by virtue of their conscious obliviousness (looking at the viewer without seemingly registering his presence as in any way significant), may work to create in the latter one or both of two effects identified by Alice N. Benston: hostility at being put in the voyeur's position and anxiety "since this insistently female world implies the avoidance, even the lack of necessity of a male presence." 50 The Holy Ghost as the intangible representative of fathers in the masculist master narrative of engendering, now becomes also the inconsequential or literally ghostly viewer. Both, however, remain implicated in the sin or crime at hand, a point to which I will return subsequently.

Be that as it may, the effect of Paula Rego's pictures is to foreground the process whereby what draws the implied male gaze is also that which places its owner (and the art tradition from which he hails, and which has trained him in that gaze), morally in a very dubious position, since after all it may be that the difference between the languid but fullygrown beauties or even the winsome and playful children of the art canon, and these girls in pain, is quantitative rather than qualitative.

Clearly there is nothing more innocent (or is there?) than the pleasure given by and derived from the contemplation of a Renoir child or a naked and infantine Botticelli cherub. Less clearly, what kind of man/citizen/moral being would be the implied male viewer sexually and aesthetically gratified by the pain of pregnant school-age girls forced into clandestine abortions? A sadist? A paedophile? An alter ego of the male who impregnated the pre-age-of-consent schoolgirls featured in nos. 4 or 6 ? The implied threat of female sexuality, let alone a deviant (because, as here, infantine) female sexuality, is therefore overshadowed in the pictures by two other factors: first, the implications of male sexual behaviour that results in the impregnation of little girls and adolescents, and second, the moral ramifications of a specular behaviour that delights in the contemplation of these disturbing "child-brides." 51

Feminist art theory in its incipient formulations trod much the same path as other areas of feminist cultural theory. For Judith Barry and Sandy Flitterman-Lewis, for example, "a radical feminist art would include an understanding of how women are constituted through social practices in culture:"

Once it is understood how women are consumed in this society it would be possible to create an aesthetics designed to subvert the consumption of women, thus avoiding the pitfalls of a politically progessive art which depicts women in the same forms as the dominant culture. ${ }^{52}$

Such art would seek, in a deconstructive move, to "play on the contradictions that inform patriarchy itself," "accepted as an already produced given" but would rather be "constructed in and through the work itself." 54 Where abortion is concerned, this demarcation between what has been and what might be imagistically possible, and the tracing of the dividing line between the two positions, which is also the dividing line between the old orthodoxy and an emerging space of aesthetic feminist dissent, instigate a neat comparison between Rego's abortion pictures and other images on the same theme but stemming from a radically different position. A representative specimen of the latter would be for example footage from Bernard Nathanson's notorious film, The Silent Scream, which purported to show what an abortion is like from the twelve-week old foetus's position. In a move that clearly highlights the objective in anti-abortion discourse of shifting attention and concern from the woman to the foetus, the film is designed and speeded up to suggest pain and avoidance of the aborting cannula, on the part of a foetus that in fact, at twelve weeks, has no cerebral cortex and therefore lacks the neurological apparatus involved in our experience of pain. The 
accompanying voice-over, in which, in Susan Faludi's words, "the truly silent cast member is the mother," describes the foetus as a child "in intrauterine exile," who is "bricked in, as it were, behind what seemed an impenetrable wall of flesh, muscle, bone and blood." 55 The pregnant woman is described as the foetus's "place of residence," and after abortion as "a bombed-out shell," "a haunted house where the tragic death of a child took place." "T6 "The aim is to talk up the foetus. [...] As they say in Hollywood, accuracy is not the point; it is the atmosphere that counts." 57

Janet Hadley comments that the power of imagery to make a point has been much more successfully deployed by anti-abortionists than pro-abortionists:

Defenders of abortion rights - with little other than the bloody coat-hanger image to remind us of the bad old days of illegal abortions - are utterly routed by the tiny feet or the manipulated trembling of the Silent Scream fetus. [...] Ours is a culture of pictures. Seeing is believing. Every newspaper editor and television news producer knows that however powerful words may be - recalling the grisly squalor of illegal abortion and its links with every kind of racketeering - it is to pictures, and above all to images that move, that people respond. No words are needed to accompany pictures of little mangled legs, hacked arms, crushed skulls. Award-winning commercials director Tony Kaye shot graphic footage of fetuses for a feature film about abortion and commented: "When you see those fetuses, it is pretty much game, set and match as far as I am concerned." 58

In light of this, where do Paula Rego's abortion pictures fit in? At one level, they fit into an agenda of blurred boundaries, since each of her lone female subjects, ostensibly alone in an empty room and presumably in a world of social conformism from which the abortion cuts her adrift, is not in fact a woman, but, with two exceptions, a child or an adolescent. And because these women are not women but girls, perturbingly, they fail to hold up their end of the binary which, were they in fact fully-grown would, according to the dictates of the anti-abortion lobby, cast them on the criminal side of the equation, as adults empowered with autonomy of decision over the life or death of the foetus. On the other side of the equation would be that absolutely vulnerable and fragile foetus, possibly doomed to termination at the hands of its bad, omnipotent mother. These pictorial protagonists tell instead a story that disturbingly escapes that facile casting, since, while being undeniably aborters, they are also simultaneously children, whose condition gestures to a more unequivocal world of adult power and to the possible abuse (or at least lack of protection) that culminated in those child pregnancies.

In the context of the confusion of categories of child and woman, the buckets that feature in several of the pictures possibly gesture to the issue of the abortion, but if so, what they establish is in fact not the separation (enmity) of would-be mother and aborted child, but rather the eerily companionable isolation of the two, in rooms that contain only them, and from the rest of the world which excludes them. And if so, what one is faced with here is not a series of juxtapositions of bad mothers and foetuses whose potential lives the former nipped in the bud, but instead repeated presentations of the theme of two lonely children, one unborn, the other unready to bear it.

These pictures also disrupt other expectations. The opponents of abortion, as was made clear in the notorious 1994 case of the Irish fourteen-year old child X, prevented from travelling to England to obtain an abortion for a pregnancy that was the outcome of rape, seldom appear to be prepared for the implications of criminalizing abortion in cases as clearcut as that particular one with regard to the assignation of blame and innocence. ${ }^{59}$ The stereotype of the abortion-seeking woman that fits more easily into the requirements of this agenda is the feckless, reckless, promiscuous and immoral, unmarried or adulterous but in 
any case always adult woman. ${ }^{60}$ The anti-abortion faction assimilates less easily the dilemmas of the severely deformed foetus, the endangered mother, the abused child-woman or the victim of rape or incest. What Paula Rego appears to have done is to home in precisely on that unresolved impasse, by depicting little girls and adolescents, females on the brink of their own life who here, willingly or unwillingly, become embroiled in the creation and destruction of someone else's. They are patriarchy's spoilt virgins, but what remains unclear is who exactly is guilty of the spoiling. Given the age of some of them, the blame, it is to be supposed, may lie elsewhere than in their own post-lapsarian concupiscence.

Continuing in a biblical vein with a twist in the tail, in the habitual composition of canonical Annunciation paintings, Mary usually figures alone, except for the ghostly intangentiality of the messenger angel who delivers her destiny to her. Her solitude or separateness (difference) underlines the exclusivity of her always sinless and now newly holy status, "alone of all her sex" as the chosen mother of God's son. ${ }^{61}$ Blessed and blissful but also lonely. Each of Rego's images represents a girl absolutely on her own in a space stripped equally of objects, angels or fellow human beings. The pictures bear further affinities to the Marian condition of lofty isolation. Paula Rego's abortion damsels therefore both echo and elaborate upon the solitude of Mary in traditional Annunciation iconography. Each female figure appears alone, but not blissfully so. Each one lies or sits without doctor or nurse, father or mother, but more to the point without her lover or impregnator to accompany her in an abortion possibly but not necessarily self-induced.

The onus of guilt in these pictures remains equally arguable, since each of these Portuguese (and therefore, in view of the existing law, almost certainly criminal) women having an abortion nonetheless carries a complex message that does not lend itself to straightforward decoding. Thus, men (and God) may be present in the making of children, but women, it is implied, are left alone in that equally God-like (albeit anti-demiurgic) act of unmaking them. At first glance this situation implies a usurpatory and even heretic move on the part of the female, since it refers to a universe where God/man may have the power over life, but the would-be demonic woman yields at least some control over death. There are, however, other implications inherent in the absence of the male beyond the act of impregnation. If, as Joanna Frueh succintly argues, "the penis stands out, the vagina does not," ${ }^{62}$ here, however, the penises implicated in these pregnancies, as well as being conspicuous for their absence become also culpable for both the former and the latter, ie. for both the pregnancies and for their own absence. And the masculine impact (the power to fertilize the female) in these pictures, particularly in view of the self-evidently non-demonic status of the girls in question, becomes not the proclamation of a male right or achievement (perpetuity of blood and lineage), but instead the fact that makes possible the indictement of both. In a countermove to the anti-abortion propaganda that in Janet Hadley's words aimed either to neglect or demonize the mother in order to "talk up the foetus," these images may be said to talk up the guilt, or at least the responsibility of the willingly evanescent male who scored and ran.

The alterity of motherhood as implied in these pictures grows increasingly in importance as one continues to ponder the theme. Motherhood, whether of a religious or secular kind, as discussed with regard to female isolation in the context of the Annunciation theme, is one of the most enduring themes in traditional iconography, and it is ongoing in contemporary figurative art by both male and more particularly female artists, whether working from within radical revisionist approaches, or in more or less traditional form (Mary Cassatt, Paula Modersohn-Becker, Käthe Kollwitz, Barbara Hepworth, Dorothea Tanning, Mary Kelly, Frieda Kahlo, Juanita McNeely).

The traditional art history establishment has alternatively hagiographized the theme, applauded its practitioners and patronized or castigated its revisionist rethinkers. ${ }^{63}$ In Paula 
Rego's contrastive abortion series, as already suggested, the casting of the mothers is in any case problematic, since her women are not adults but girls. More to the point however, these works are not about becoming or being a mother, but about not becoming so. Their theme is an act socially defined as the unnatural and premature termination of the life-cycle, and as such stands coterminous with other forms of aggression such as castration, infanticide and homicide.

For Cassandra L. Langer, feminist revisionist art must involve art forms explicitly conscious of women's oppression due to gender, an art that "understands that women exist for the patriarchy: to propagate, to carry on the male name, and to assure a legitimate passage of the father's property and wealth to a designated heir." ${ }^{64}$ In art tradition, the dangerous, infanticidal mother finds expression more commonly through the metamorphosed (and therefore to some extent side-stepping) device of presenting a gallery of usually biblical belles dames sans merci who are not necessarily or primarily mothers, ie. who are not principally feared in their maternal/annihilatory capacities: (Delilah, Judith, Salome, etc.). Hasty refuge from the nightmare of murderous mothers is sought, furthermore, in the omnipresent, enduring and numerous (safety in numbers) depictions of the Virgin and Child throughout centuries of Western iconography. The sheer numerical balance of pictures painted under the themes respectively of virgin and whore, vastly (and, for the panicked male psyche, reassuringly) favours good over bad women/mothers, with beatific madonnas and their earthly sidekicks (the wives and mothers of traditional portraiture) easily outnumbering all the other faces of womankind put together. Be that as it may, in any case the timeless and distinct categories of Mary and Eve, Virgin and Whore, Mother and Killer are each in their own way reassuring, precisely because they remain clearly compartmentalized: complementary yet distinct, commensurate but absolutely separate, meaninfully antithetical. Because they are different and mutually exclusive, they enable the viewer to know what's what morally, and to cope with evil while enjoying goodness. It is the dissolution of the demarcating boundaries between the two opposites, and the ensuing possibility of a fusion of categories, that poses the real threat to a status quo that depends on the continuing safety of a preserved and understood difference between Good and Evil. It is that threat that underpins the narrative processes Paula Rego puts in motion in this series of pictures. These images convey something - child pregnancy - which is morally unspeakable and almost unutterable, something which words hardly can, but images do convey. More unorthodoxly, even, they direct viewer compassion primarily to the aborting mother. In doing so, they compromise obedience to a conservative received morality: the understanding that abortion is a crime/sin on the part of the mother and that she ought to suffer for it. The effect is that of undermining the possibility of conformity with definitions of what in this situation is seen to constitute a crime warranting punishment, or of who is deemed to be guilty of it.

Abortion may be the thematic antithesis of blessed motherhood, but in itself it need not pose a serious threat to an orthodoxy that after all has coped with equanimity, indeed wallowed pictorially and at length, in the representation of any number of biblical and historical murderesses, and enjoyed the frisson entailed in doing so. This hypocrisy is annotated in the only picture in this cycle whose subject is not an aborting girl (n. 9). The homely matron who has performed or is about to perform an abortion and currently wipes the basin presumably used for the containment of the foetus is a perfect representation, through her motherly physical presence and house-wifely cleaning attributes, of everything domestic and maternal that Salazar's social blueprint prescribed for women. She could be anybody's mother, aunt, domestic servant, the very antithesis, in short, of the backstreet abortionist.

Clearly, however, being the abortionist that she is here (and in Portugal, necessarily, in view of the prevailing laws, a backstreet one), she contravenes all that is conventionally and 
socially acceptable. Paradoxically, however, her actions also help to sweep under the carpet a disallowed pregnancy, and therefore collude in maintaining the fiction of a God-fearing nation in which ideally girls did not to become pregnant before they became wives. Abortion, therefore, particularly if made possible by motherly figures such as this one, both defies and shores up the fiction of a state-defined female sexuality successfully contained within authorized boundaries. It defies it because it covers up illicit sexual behaviour; but it promotes its apparent standing by helping to dispose of the illegitimate children who would be the living proof that, after all, in this, God's country, all is not as it ought to be.

The figure in question here represents a performance on the cusp between the two categories (good woman/bad woman, mother/abortionist, life giver/life taker, madonna/whore, mater dolorosa/fallen woman). That performance simultaneously dissolves the boundary between prescribed and proscribed roles and behaviour (mother and abortionist, mothering and killing), and reaffirms it. It dissolves the boundary because the same figure simultaneously occupies both roles, thus denying their mutual exclusivity. And it reaffirms it because, in Salazar's Portugal, many mothers worth their salt must have been and still must be occasionally forced to turn into unwilling accomplices to the backstreet abortions of their foetal grandchildren, in order to safeguard the respectability (and the possibility of future happiness) of their beloved daughters, in a social context in which almost the only label available for an unmarried girl who became a mother was that of whore. This complicity between mother and daughter, which helped to conceal the unauthorized sexual activities that led to the pregnancy, paradoxically also colluded in perpetuating the fiction of a society in which girls were only ever good girls.

The motherly figure who goes along with, or even carries out the abortion, therefore, simultaneously collaborates with and threatens the status quo. She is the accomplice in a crime, which, however, upholds the rule of morality, by conveniently concealing the evidence of sexual misdemeanours themselves more fundamentally threatening to the perpetuity of the established order. The action of the bivalent Janus-figure (mother and abortionist), by casting her in both roles simultaneously, literally kicks over the traces of demarcating lines whose function is to keep each moral category (virgin or whore) sealed off from the other. While erasing the boundary between the two, however, the mother/abortionist, paradoxically, also polices and preserves that line, which is the barrier that prevents her daughter's angel status from slipping into the counterpoint of the fallen woman, and becoming indistinguishable from it. And finally, the denial or cover-up of female transgression appears, after all, to have served the interests of both the transgressor and the law transgressed, in a status quo that depended and arguably still depends at present on believing that women hail from the heart of Mary, not the loins of Eve.

In Portuguese proverbial folklore "a grandmother is a mother twofold," 65 a saying that encodes the notion of cumulative maternal love down the generations. A woman's grandchildren, according to this homely nugget, may be twice as beloved by her as her own child was. If so, however, Paula Rego once again plays disruptive games with her Portuguese heritage of received wisdom. The mother's/grandmother's presence, which here is interpreted as the palimpsest of generations of women caught up in the paradox of helping to kill a grandchild in order to protect a child, hovers understatedly in several of the pictures. Not only, although more obviously, in the matronly figure in n. 9, but, more allusively, in the shape of a variety of old-fashioned props which are the domestic débris of older generations of women, such as for example the motherly shawl draped over an armchair as though over a pair of plump and cosy shoulders, in n.6.

Ultimately, however, it is through the casting, dressing and accessorizing of her aborting women that Paula Rego plays her riskiest games. These children and adolescents illequipped to be mothers gesture towards the possibility of a maternity which for them ought 
to have been far in the future, but which they reject here and now. However, in rejecting that hallowed female role, officially declared as the only one available to a good woman, they cannot immediately nor easily be re-cast as the latter's counterpoint, the runaway madonna or fallen angel, demoness or hell hag. They are girls who ought not to become mothers because they are young enough themselves still to need a mother to take them to school in their uniform (n. $4 ; n$. 6). If it is true that "among the variety of ways [maternity] has been portrayed by artists, that of the 'happy mother' is perhaps one of the most enduring images in traditional art history," in Paula Rego's recent work, whose referent is Salazar's and postreferendum Portugal's ostentatious matriolatry, the possibility of a series of would-be maternities is ruptured by betrayal and absence.

\section{Civic Painting: Art For the Public Good}

In the early decades of the eighteenth century in England, the most influential attempts to provide the practice of painting with a theory were those which adopted the terms of value of the discourse we now describe as civic humanism. The republic of the fine arts was understood to be structured as a political republic; the most dignified function to which painting could aspire was the promotion of the public virtues; and the genres of painting were ranked according to their tendency to promote them. As only the free citizen members of the political republic could exhibit those virtues, the highest genre, history-painting, was primarily addressed to them, and it addressed them rhetorically, as an orator addresses an audience of citizens who are his equals, and persuades them to act in the interests of the public. ${ }^{66}$

I should wish to conclude with a proposal. Paula Rego's work of the last decade, conveniently, from the point of view of linking it chronologically to the above quotation, has included some recent works sourced in the eighteenth-century painter Hogarth, possibly British art's best known social commentator and pictorial moralist. The cruel satirist trait that both share and which perhaps initially attracted her to him as a source, gestures towards another trait common to both, namely the penchant for morality with a twist.

John Barrell has traced a shift in the perception of painting's function in the eighteenth century, from the promotion of public to private virtues. It is in the context of this shift that he locates the rise of a civic humanist theory of painting that sought to recuperate the commitment to and belief in art as performing a public function in society, namely the fostering of a public spirit, and a passion for the "common weal." ${ }^{67}$ Curiously, and not irrelevantly here, the civic humanist theory of painting presupposed the exclusion of women equally as producers and partakers of history-painting, the genre par excellence of civic art:

That theory assumes that, as Shaftesbury had put it, 'Ladies hate the great manner'; that women cannot understand history-paintings, which are public and idealised works, the comprehension of which demands an understanding of public virtue, an ability to generalize, and 'an acquaintance with the grand outline of human nature', which (whether by nature or nurture) is denied to women, who are obliged to remain 'satisfied with common nature'. If the 'ladies' cannot discuss history-paintings, that is because it has been presumed impossible for them to learn how to do so. Portraits, however, work in terms of 'personal' ideas; they aim to present particular likenesses; where they represent virtue, they favour the private virtues; and they gratify the vanity of those who sit for them, and so of women especially, who are known to be especially vain. That women are happy to 
discuss portraits only confirms their inability to comprehend the higher, the public genre of art. ${ }^{68}$

In view of this, Paula Rego's abortion pastels, as is the case indeed with the vast majority of her work which is arguably classifiable as history-painting, offers us a triple twist. First, simply by virtue of being the work of a woman engaged, albeit largely antagonistically, in dialogue with the master narratives of her country (or countries Portugal and Britain) in different periods. Second, because the civic message her paintings extend and the public service they seek to render is the advancement of areas of ethical debate (here specifically abortion), the conclusion of which, whatever the final position adopted, will probably necessitate a paradigmatic shift in the attribution of guilt and blamelessness in at least some cases of voluntary termination of pregnancy. And third because, as these images become reinscribed within the specific historical referent that anchors them, and as the ghosts of Catholic Ultra-Montanist intolerance ${ }^{69}$ return and defeat even constitutional safeguards, it is the very fabric of recent democratic emancipation which is exposed in all its fragility.

Between 1997 and 1999 Paula Rego created a series of pictures that variously refer to problematic childbirths that either do not come to fruition (by reason of abortion), or are curtailed by infanticide (through the association made between the 1998 Father Amaro series of pastels and the original novel, in which a priest instigates the death of his inconvenient newborn son). ${ }^{70}$ Long stretches of time separate the mid-1870's publication of the novel that inspired the Father Amaro images, the mid-1970's revolution which brought about the collapse of Salazar's Estado Novo, and the abortion referendum events of 1998, which directly motivated these images. Time has passed, but after all, it would seem, or at least in Paula Rego's apocalyptic vision, little has altered in significant areas of women's lives in a country in some respects much unchanged. I will conclude with the curiously lyrical words of an embryologist:

Looking through the microscope at the physical structure of embryonic man, I see no heaven-bound chariot of the soul, but only a frail congeries of animal cells, fraught indeed with promise beyond all other embryonic creatures, but of necessity bound to grow and to organize itself as an animal if it is to be a man. Humbly employing such vision as may be granted to an embryologist, I declare my conviction that the spirit of man - all that makes him more than a beast and carries him onward with hope and sacrifice - comes not as a highborn tenant from afar but as a latent potentiality of the body. [...] The spirit, with the body, must grow and differentiate, organizing its inner self as it grows, strengthening itself by contact with the world, winning its title to glory by struggle and achievement. $^{71}$

\section{NOTES}

A longer version of this essay will be published in a forthcoming monograph on Paula Rego: Paula Rego's Map of Memory: National and Sexual Politics. Aldershot, UK and Burlington, USA: Ashgate (2003).

${ }^{1}$ For the present purposes the difference between New Historicism and Cultural Materialism will not be debated with any degree of theoretical depth. For an insightful discussion into these issues, consult Jeremy Hawthorn, Cunning Passages: New Historicism, 
Cultural Materialism and Marxism in the Contemporary Literary Debate. London, New York, Sidney and Auckland: Edward Arnold (1996).

${ }^{2}$ Ibid., 3.

${ }^{3}$ Jacques Derrida, Of Grammatology. Trans. Gayatri Chakravorti Spivak. Baltimore and London: Johns Hopkins UP (1976), 158.

${ }^{4}$ For a further discussion of this, consult Patricia Waugh, Practising Postmodernism Reading Modernism. London: Edward Arnold (1992).

5 Jean-François Lyotard, The Postmodern Condition: A Report on Knowledge. Geoff Bennington and Brian Massumi (tranls.). Minneapolis: U of Minnesota P (1984), 26.

${ }^{6}$ Norman Bryson, "Intertextuality and Visual Poetics" in Style, vol. 22, n. 2 (Summer 1988), 187.

${ }^{7}$ Hawthorn, op.cit., 29.

${ }^{8}$ Linda Hutcheon, "Fringe Interference: Postmodern Border Tensions" in Style, op.cit., 300 .

${ }^{9}$ Ibid.

${ }^{10}$ Deborah Lipstadt, Denying the Holocaust. New York: Plume Books (1994), 21.

${ }^{11}$ Saul Friedlander (ed.), Probing the Limits of Representation: Nazism and the Final Solution. Cambridge, Mass and London: Harvard UP (1992), 20.

${ }^{12}$ Mieke Bal, "De-discipling the Eye" in Critical Inquiry, vol. 16, n. 3 (Spring 1990), 507.

${ }^{13}$ Naomi Schor, Reading in Detail: Aesthetics and the Feminine. New York and London: Methuen (1987).

${ }^{14}$ Mieke Bal, op.cit., 508.

${ }^{15}$ Lloyd Cole, My Baby, My Body, My Choice. Maidenhead: Lloyd Cole (1992), 51.

${ }^{16}$ Anti-abortion activism in the United States includes but does not necessarily entail a Catholic component. Other Christian interests are predominantly involved.

${ }^{17}$ Janet Hadley, Abortion: Between Freedom and Necessity. London: Virago (1996), 153.

${ }^{18}$ Ibid., 154.

${ }^{19}$ Genesis, 3:16.

${ }^{20}$ Marina Warner, Alone of All Her Sex: The Myth and Cult of the Virgin Mary. London: Picador (1985), 60-61.

${ }^{21}$ Ibid., 57.

22 Ibid., 337.

${ }^{23}$ Ibid., 284, 289.

${ }^{24}$ Ibid., 338.

${ }^{25}$ Ibid., 337.

${ }^{26}$ These pronouncements by Salazar, made in the course of a series of interviews given throughout the 1950s and 60s, are quoted in Darlene J. Sadlier, The Question of How: Women Writers and Portuguese Literature (New York and London: Greenwood Press, 1989), 2-3.

${ }^{27}$ Ibid., 3.

${ }^{28}$ Quoted in John McEwen, Paula Rego. London: Phaidon (1997), 27.

${ }^{29}$ Sadlier, op.cit., 123, italics ours.

${ }^{30}$ Paula Rego, The Sin of Father Amaro. Londres: Dulwich Picture Gallery (1998).

Untitled. Lisboa: Centro de Arte Moderna José de Azeredo Perdigão (1999).

${ }^{31}$ Portugal: Situação das Mulheres. Lisbon: Comissão para a Igualdade e Para os Direitos das Mulheres/Presidência do Conselho de Ministros (1995), 146-47.

${ }^{32}$ Mafalda Durão Ferreira, Expresso, n. 1319, 7 February 1998, 11.

${ }^{33}$ Graça Rosendo, op.cit., 58-64. 
${ }^{34}$ See for example paintings such as Salazar Vomiting the Homeland (1960), When We Used to Have a House in the Country (1961) and Iberian Dawn (1962), which all engaged in open polemic with Salazarismo at home and its colonial operations, in the last decade and a half of the regime.

${ }^{35}$ John T. Noonan, "How to Argue about Abortion" in Nancy C. Ostheimer and John M. Ostheimer, Life or Death: Who Controls? New York: Springer Publishing Company (1976), 135.

${ }^{36}$ I am grateful to Michael Brick for first suggesting this idea to me.

${ }^{37}$ John Berger, Ways of Seeing. Harmondsworth: Penguin (1972), 47.

${ }^{38}$ Laura Mulvey, "Visual Pleasure and Narrative Cinema," Screen 16, n. 3 (Autumn 1975), 18.

Visual and other pleasures, Basingstoke: Macmillan (1989).

${ }^{39}$ Lise Vogel, "Fine Arts and Feminism: the Awakening Conscience" in Arlene Raven, Cassandra L. Langer and Joanna Frueh (eds.), Feminist Art Criticism: An Anthology. Ann Arbor and London: UMI Research Press (1988), 46.

${ }^{40}$ Carol Duncan, "The Aesthetics of Power in Modern Erotic Art" in Feminist Art Criticism, op.cit., 59.

${ }^{41}$ Ibid., 59-60.

${ }^{42}$ Griselda Pollock, Differencing the Canon: Feminist Desire and the Writing of Art's Histories. London and New York: Routledge (1999), 103.

${ }^{43}$ Duncan, 60.

${ }^{44}$ Germaine Greer, The Female Eunuch. New York: Farrar, Straus \& Giroux (1972), 57.

${ }^{45}$ Rosemary Betterton, 'Maternal Figures: The Maternal Nude in the work of Käthe Kollwitz and Paula Modersohn Becker,' in Griselda Pollock (ed.), Generations \& Geographies in the Visual Arts: Feminist Readings. London and New York: Routledge (1996), 159-79.

46 Ibid., 175.

47 Angela Carter, The Sadeian Woman: An Exercise in Cultural History. London: Virago (1979), 17-20.

${ }^{48}$ Aristotle, "On the Art of Poetry" in Aristotle, Horace, Longinus, Classical Literary Criticism. London: Penguin (1965), 49-51.

${ }^{49} \mathrm{Bal}$, op.cit., 515 .

${ }^{50}$ Alice N. Benston, "Framing and Being Framed by Art: Theatricality and Voyeurism in Balthus" in Style, op.cit., 356.

${ }^{51}$ It may be interesting to bear in mind, in this context, that if the term "virgin" means, as some scholars have argued, either a very young girl who is however deemed to be marriageable, or a girl who becomes fertile and pregnant before her first menstruation actually occurs, in other words before she is officially a woman to the naked eye, the youthful Virgin Mary who has inspired so many painters, possibly impregnated before her pubescent state could be biologically ascertained, was herself therefore still a child.

52 Judith Barry and Sandy Flitterman-Lewis, "Textual Strategies: The Politics of ArtMaking," in Feminist Art Criticism, op.cit., 88.

${ }_{54}^{53}$ Ibid., 94.

${ }^{54}$ Ibid.

${ }^{55}$ Susan Faludi, Backlash: The Undeclared War Against Women. London: Chattus \& Windus (1991), 459.

${ }^{56}$ Ibid.

${ }^{57}$ Hadley, op.cit., 149.

${ }^{58}$ Ibid., 150. 
${ }^{59}$ Hadley, op.cit., 15-23.

${ }^{60}$ Kenny, op.cit., 14; Hadley, op.cit., 31.

${ }^{61}$ In the Gospels rendering of the Annunciation (St. Luke 1:26-38) Mary tellingly evinces initial reluctance to accept her fate, a reaction perhaps the less surprising bearing in mind what is known historically about the severity of the penalty associated with crimes of female fornication and extra-marital pregnancy. And Joseph, too, experiences doubts about this event (St. Matthew 1:19).

62 Joanna Frueh, "Towards a Feminist Theory of Art Criticism" in Feminist Art Criticism, op.cit., 161.

${ }^{63}$ In Mary Cassatt's case, for example, "her childlessness was pointed to by patriarchal explicators as the reason for her choice of theme. Implicit in this interpretation was the notion that she was compensating for not having fulfilled her 'natural destiny' as wife and mother by painting a wished-for reality. This sort of insinuation, like the spectre of the lesbian, is meant to warn more "natural' women [against] following such examples." Cassandra L. Langer, "Against the Grain: A Working Gynergenic Art Criticism" in Feminist Art Criticism, op.cit., 124.

${ }^{64}$ Ibid., 111.

${ }^{65}$ The saying in Portuguese is "uma avó é duas vezes mãe."

${ }^{66}$ John Barrell, The Political Theory of Painting from Reynolds to Hazlitt: The Body of the Public. New Haven and London: Yale UP (1986), 1.

${ }^{67}$ Ibid., 5.

${ }^{68}$ Ibid., 68.

${ }^{69}$ The term Ultramontanismo refers to the links forged at various periods between the State and the Vatican, and which included two Concordats, one in 1847 and one in 1940.

${ }^{70}$ Paula Rego, The Sin of Father Amaro, op.cit. Eça de Queirós; $O$ Crime do Padre Amaro. Lisbon: Livros do Brasil (s.d). The Sin of Father Amaro. Trans. Nan Flanaghan. London: Carcanet (1994).

${ }^{71}$ George W. Corner, “An Embryologist's View” in Abortion in a Changing World, vol. 1, op.cit., 14-15. 
ILLUSTRATIONS

All reproductions are from: Paula Rego, Untitled. Centro de Arte Moderna José de Azeredo Perdigão, Fundação Calouste Gulbenkian. Lisbon (1999), from the exhibition held between 18 May - August 1999.

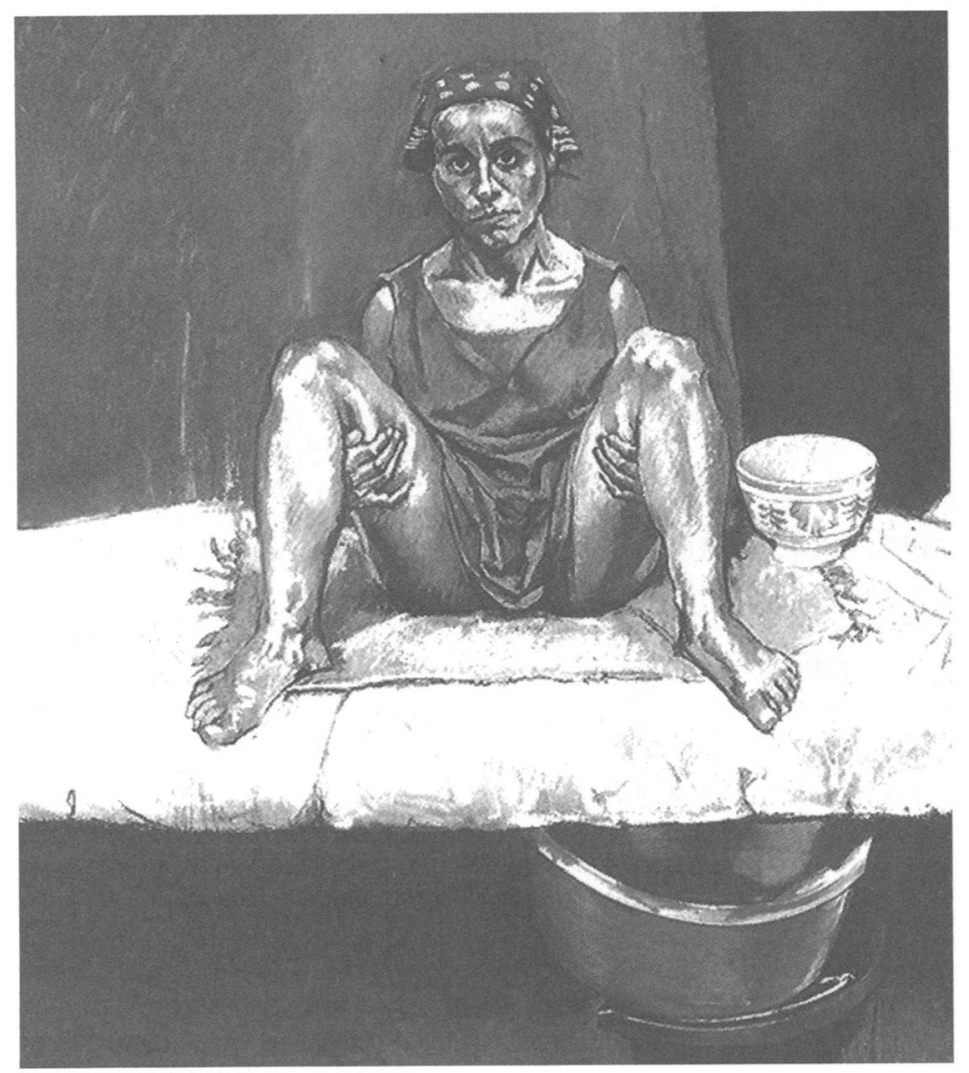

Untitled $\mathrm{N}^{\circ} 1$ 


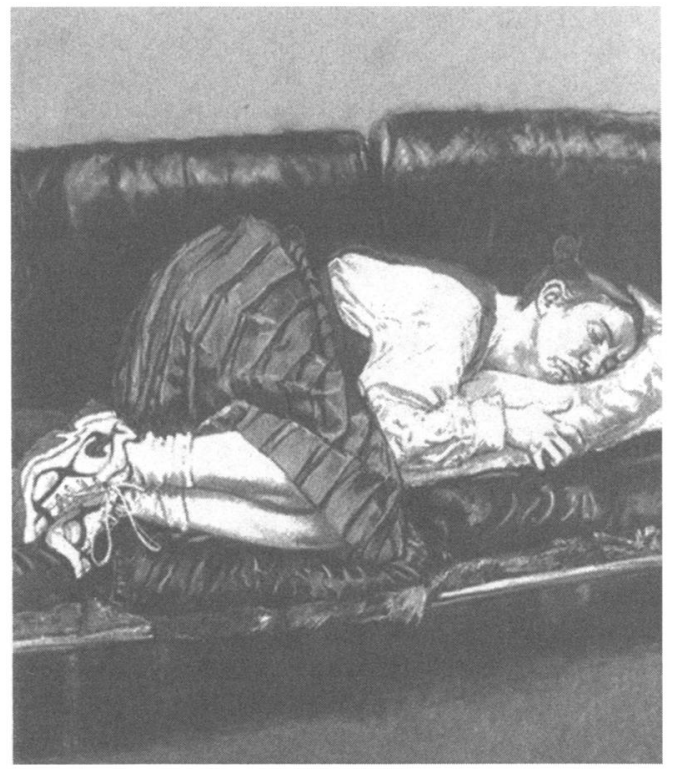

Untitled $\mathrm{N}^{\circ} 4$

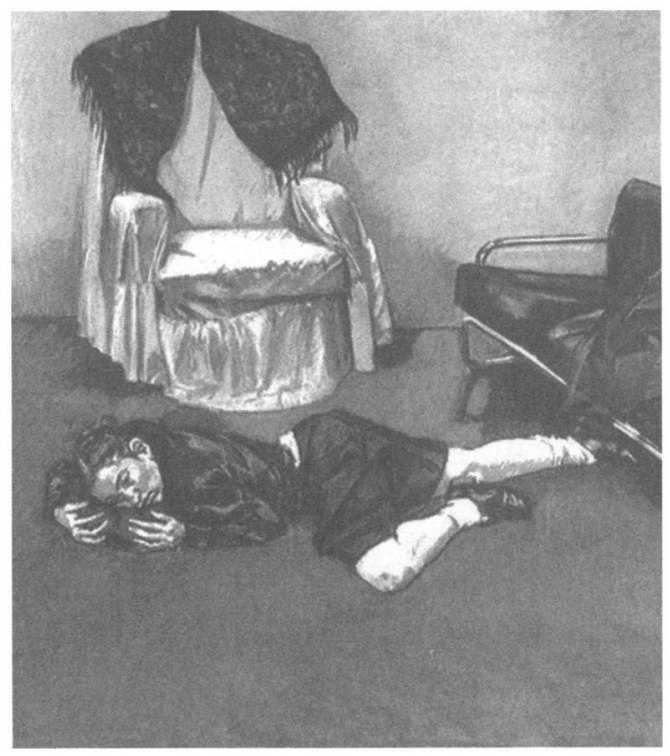

Untitled $\mathrm{N}^{\circ} 6$ 


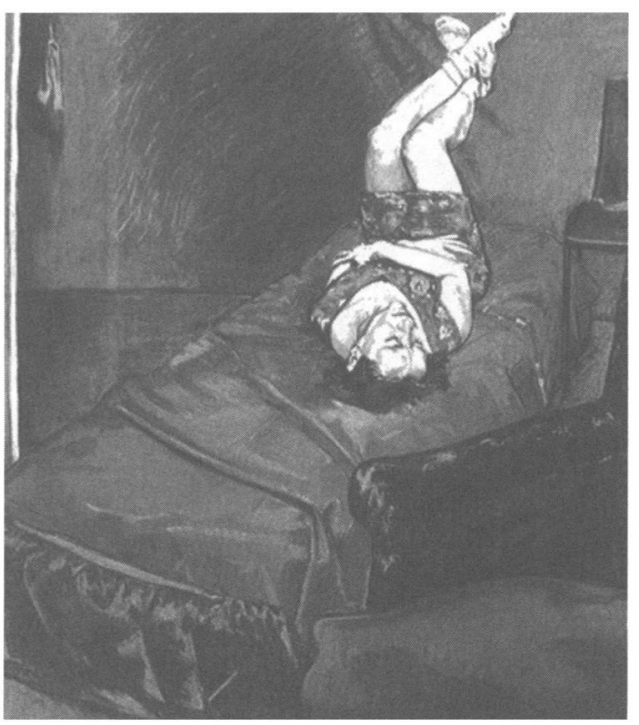

Untitled $\mathrm{N}^{\circ} 7$

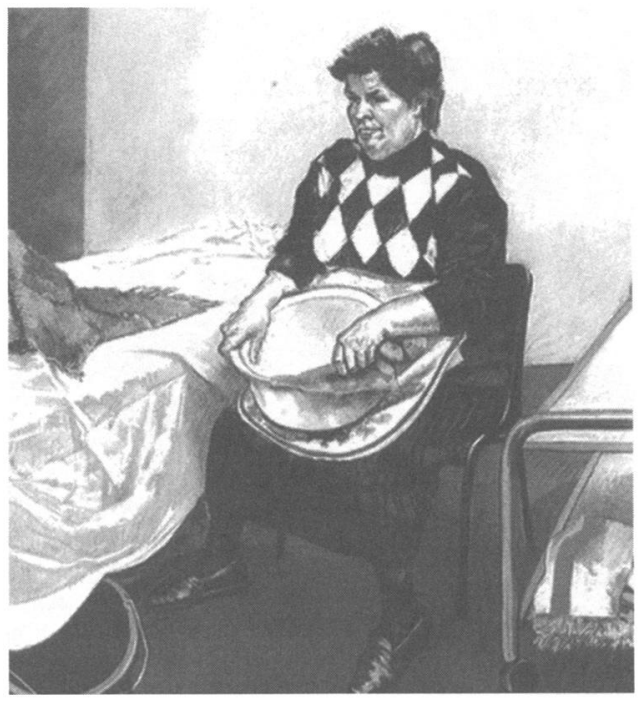

Untitled $\mathrm{N}^{\circ} 9$ 


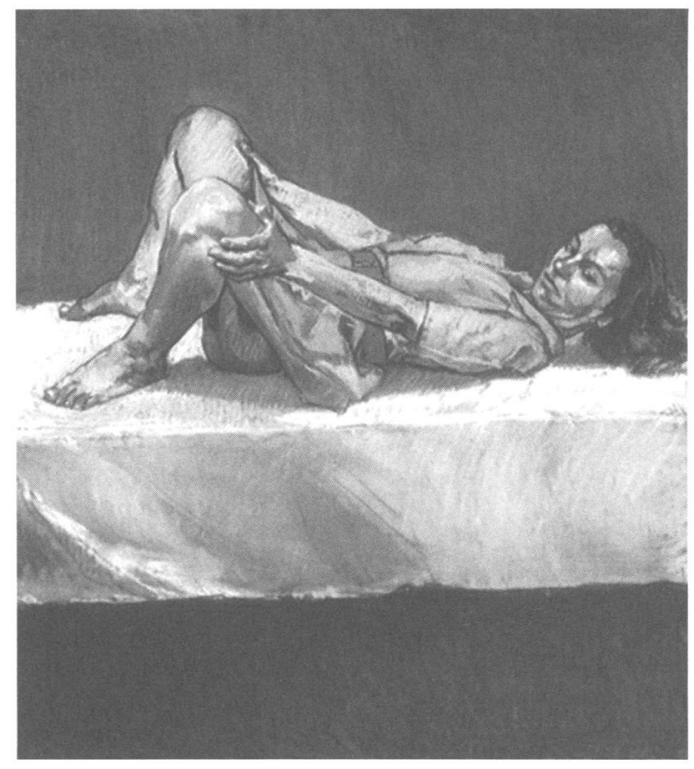

Triptych b

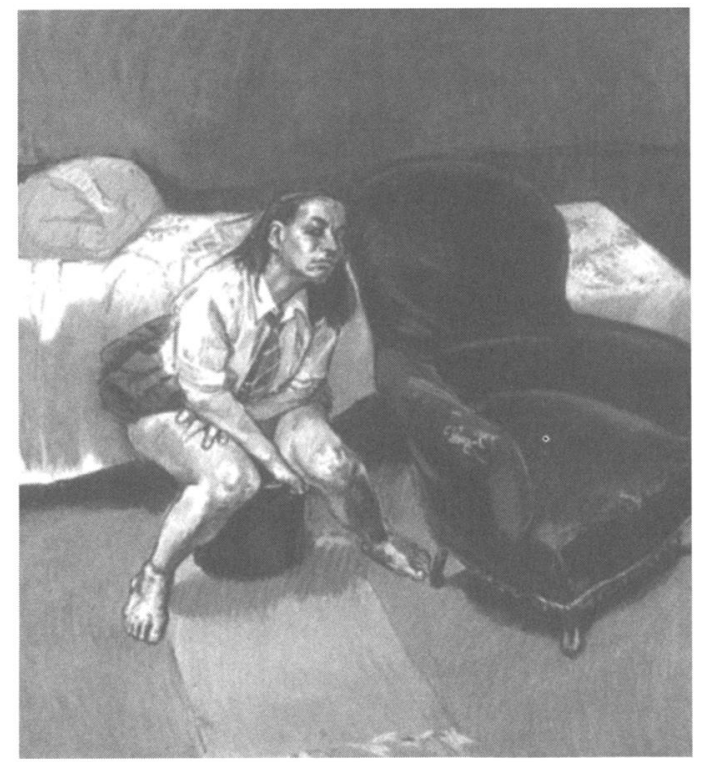

Triptych c 